Book review

\title{
Winners and Losers of the SEB Reforms: an organizational analysis
}

Joel Ruet

Publication No. 1, 2001 French Research Institutes in India $85 \mathrm{pp}$.

S L Rao

Distinguished Fellow, TERI, Darbari Seth Block, Habitat Place, Lodhi Road, New Delhi - 110 003, India

International Journal of Regulation and Governance 2(1): 75-76

This short study is based primarily on observations of electricity operations in Andhra Pradesh, Haryana, and Orissa. It makes the point that the reform process now generally accepted for SEBs (state electricity boards) - of unbundling, corporatization, privatization, and independent regulation - ignores a fundamental weakness in the electricity sector, particularly in the states.

$T$ he SEBS have not been run with a view to maximize efficiency and effectiveness, like a corporate enterprise would normally be. They have been given commercially based accounting rules in 1985 but are not companies under the law. Governments contend that the 'most serious problem facing the power sector is the lack of investment funds'. But, in fact, substantial improvements - for example, in reducing technical losses, prioritizing transmission over generation investments - were possible within the financial conditions. The World Bank identified 'political interference' but the SEBs neither enforced normal remedies to collect bills, nor took bold measures to eliminate non-technical losses. The basic problem is that SEBS are run on executive instructions from governments, eliminating autonomy, accountability, and innovation by SEB employees. T he SE Bs suffer from cost inefficiencies. I rrational management has to change, for which people have to be changed as has the decision-making process.

The SE Bs are characterized by the absence of internal discretionary power and an integrated information system. There is a 
predominance of paper work instead of a focus on cost. Budgets are paper budgets with no managerial freedom to make decisions. Officers spend most of their time on clearing formal requests. Every decision is taken collegially, many times with the involvement of the head office. Information is not integrated and reports cannot be used as centralized managerial tools. Reporting on collections and losses is ex post, precluding any monitoring. Accounts are incomplete and inconsistent. There is no formal discretionary power. Preventive maintenance is negligible. M ost of the time is spent on solving breakdowns. Instead of decisions, procedures are followed and paper work is completed. Revenue recovery is secondary. The notion of cost is absent. Public accountancy and not commercial accountancy is usually followed at all levels. What is required is 'enterprization', moving from administrative to enterprise in decision-making. This must precede any change in ownership.

In all the debates on electricity reforms, the basic issue of managerial styles has been ignored. U nless people, systems, and procedures are changed, no reforms will be effective. This is an important lesson for electricity regulators who find themselves foxed by the apparent nonchalance with which SE B officials accept partial and wrong information, frequently change information and their demands, cannot impose discipline on their employees, and apply misplaced priorities to all aspects of the system. Regulators might be well advised to devote attention to organizational issues of SEBs if they expect their orders to be implemented by SE Bs or their successor bodies. 